Journal of Telenursing (JOTING)

Volume 3, Nomor 1, Juni 2021

e-ISSN: 2684-8988

p-ISSN: 2684-8996

DOI: https://doi.org/10.31539/joting.v3i1.2113

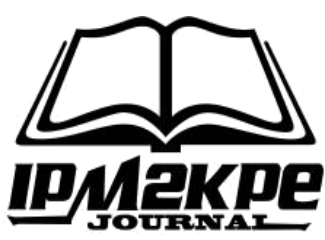

\title{
PEMBERIAN POSISI SEMI FOWLER MENINGKATKAN SATURASI OKSIGEN PASIEN PPOK
}

\author{
Ni Made Dwi Yunica Astriani ${ }^{1}$, Putu Wahyu Sri Juniantari Sandy ${ }^{2}$, \\ Made Mahaguna Putra ${ }^{3}$, Mochamad Heri ${ }^{4}$ \\ Sekolah Tinggi Ilmu Kesehatan Buleleng ${ }^{1,2,3,4}$ \\ astrianiyunica1@gmail.com ${ }^{1}$
}

\begin{abstract}
ABSTRAK
Penelitian ini bertujuan adalah untuk mengetahui keefektifan pemberian posisi Semi Fowler terhadap saturasi oksigen pada pasien PPOK. Desain penelitian menggunakan rancangan One Group Pre-Post Test Design. Hasil penelitian pada 30 responden PPOK menunjukkan bahwa rata-rata nilai saturasi oksigen sebelum diberikan posisi Semi Fowler yaitu 89,47. Setelah diberikan posisi Semi Fowler selama 30 menit, rata-rata nilai saturasi oksigen pasien PPOK mengalami peningkatan yaitu 95,83. Berdasarkan hasil dari uji paired t-test menunjukkan bahwa hasil sig (2-tailed) atau nilai $\mathrm{r}=0,0001$. Simpulan, terdapat peningkatan antara nilai saturasi oksigen setelah diberikan posisi Semi Fowler.
\end{abstract}

Kata Kunci: PPOK, Saturasi Oksigen, Semi Fowler

\section{ABSTRACT}

This study aims to determine the effectiveness of the Semi Fowler position on oxygen saturation in COPD patients. The research design used the One Group Pre-Post Test Design. The research results on 30 COPD respondents showed that the average value of oxygen saturation before being given the Semi Fowler position was 89.47. After being given the Semi Fowler position for 30 minutes, the average oxygen saturation value of COPD patients increased, namely 95.83. The results of the paired t-test show that the results are sig (2-tailed) or the value of $r=0.0001$. In conclusion, there is an increase in the oxygen saturation values after being given the Semi Fowler position.

Keywords: COPD, Oxygen Saturation, Semi Fowler

\section{PENDAHULUAN}

Prevalensi merokok pada populasi usia 10-18 tahun meningkat dari 7,2\% pada tahun 2013 menjadi 9,1\% pada tahun 2018. Prevalensi merokok di Bali meningkat dari 20\% pada tahun 2013 dan 23,5\% tahun 2018 (Kementerian Kesehatan RI, 2018). Penyakit Paru Obstruktif Kronik (PPOK) adalah suatu penyakit yang disebabkan oleh terhambatnya arus udara pernafasan dan bersifat tidak menular. ISPA di Kabupaten Buleleng merupakan penyakit yang tidak menular dan menduduki peringkat kedua dengan 13.240 kasus (Dinas Kesehatan, 2019). Terapi farmakologis PPOK dapat diberikan dengan nebulizer untuk mengencerkan dahak/mukus. Adapun terapi non farmakologis PPOK dapat diberikan dengan relaksasi nafas dan perubahan posisi. 
Nebulizer dan posisi Semi Fowler dapat diberikan secara bersama-sama untuk dapat membuka jalan nafas (Ummah \& Alivian, 2020).

Tanda dan gejala yang dialami pasien PPOK adalah sesak nafas secara kronis dan menahun serta batuk-batuk (J et al., 2020; Padila et al., 2020). Batuk yang di rasakan oleh pasien PPOK disebabkan oleh kebiasaan merokok yang dilakukan oleh kebanyakan laki-laki sehingga angka kejadian PPOK sebagian besar terjadi pada laki-laki (Astriani et al., 2020; Padila et al., 2019; Pratama et al., 2019). Upaya yang dilakukan untuk menurunkan sesak nafas yaitu dengan terapi non farmakologis. Salah satu nya adalah pemberian posisi Semi Fowler. Penelitian yang dilakukan oleh Sahrudi \& Satria (2020) mengenai pemberian posisi Semi Fowler pada 20 orang responden penderita asma bronkial menunjukkan bahwa terjadi penurunan frekuensi nafas dari 28x/menit menjadi 21x/menit. Posisi Semi Fowler bisa meningkatkan ekspansi paru dan menurunkan frekuensi sesak napas dikarenakan dapat membantu otot pernapasan mengembang maksimal.

Studi pendahuluan yang dilakukan di RS Santi Graha menunjukkan bahwa jumlah penderita PPOK dalam dua bulan terakhir yaitu sebanyak 60 orang, dimana rata-rata kunjungan penderita PPOK setiap bulan sebanyak 30 orang. Hasil observasi pada 5 pasien PPOK memperlihatkan bahwa rata-rata nilai saturasi pasien PPOK yang baru berobat ke IGD adalah kurang dari 90\%. Selain itu, tiga orang pasien di IGD yang diwawancara menyatakan bahwa ketika masuk ke RS, mereka langsung dipasang $\mathrm{O}_{2}$ dan masih merasa kurang nyaman. Begitu juga saat pasien merasa sesak, mereka hanya dipasang $\mathrm{O}_{2}$.

Sejauh ini belum ada penelitian yang mengkaji tentang pemberian posisi Semi Fowler dalam meningkatkan saturasi oksigen pasien PPOK. Dengan adanya permasalahan yang telah dijabarkan oleh peneliti di atas, maka peneliti tertarik untuk mencoba menerapkan posisi Semi Fowler untuk meningkatkan nilai saturasi oksigen pasien.

\section{METODE PENELITIAN}

Penelitian ini memberikan perlakuan atau intervensi pada objek yang akan diteliti. Penelitian ini merupakan penelitian eksperimen, dimana subjek penelitiannya adalah pasien PPOK di RS Santi Graha. Teknik sampling yang digunakan adalah teknik purposive sampling. Peneliti menentukan sampel dengan pertimbangan tertentu yang dipandang dapat memberikan data secara maksimal dengan jumlah sampel 30 orang responden. Desain yang digunakan dalam penelitian ini yaitu One Group Pre-Test dan Post-Test. Pre-test dilakukan untuk mengetahui nilai saturasi oksigen pada pasien PPOK sebelum diberikan posisi Semi Fowler. Setelah itu, peneliti menerapkan posisi Semi Fowler pada pasien PPOK selama 30 menit dan dilakukan post-test untuk melihat perubahan saturasi oksigen. Kaji etik dalam penelitian ini dilakukan oleh Komite Etik Penelitian Kesehatan (KEPK) Sekolah Tinggi Ilmu Kesehatan Buleleng. 


\section{HASIL PENELITIAN}

Tabel. 1

Distribusi Frekuensi Usia

\begin{tabular}{ccc}
\hline Umur & Jumlah & Persentase (\%) \\
\hline $40-45$ & 7 & 23.3 \\
$46-50$ & 14 & 46.7 \\
$51-55$ & 9 & 30 \\
\hline Total & 30 & 100 \\
\hline
\end{tabular}

Berdasarkan tabel 1, data menunjukkan bahwa sebagian besar responden berumur 46-50 tahun sebanyak 14 orang (47\%) dan terendah adalah pada umur 40-45 tahun yaitu sebanyak 7 orang $(23 \%)$.

Tabel. 2

Distribusi Frekuensi Jenis Kelamin

\begin{tabular}{ccc}
\hline Usia & Frekuensi (f) & Persentase (\%) \\
\hline Laki-laki & 23 & 76.7 \\
Perempuan & 7 & 23.3 \\
\hline Total & 30 & 100 \\
\hline
\end{tabular}

Berdasarkan tabel 2, data memperlihatkan bahwa distribusi frekuensi responden berdasarkan jenis kelamin sebagian besar adalah berjenis kelamin laki-laki yang berjumlah 23 orang ( $77 \%$ ) dan 7 orang $(23 \%)$ responden berjenis kelamin perempuan.

Tabel. 3

Saturasi Oksigen Responden Sebelum Diberikan Posisi Semi Fowler

\begin{tabular}{ccccccc}
\hline & $\mathrm{N}$ & Mean & Min & Max & SD & $95 \%$ CI \\
\hline Pre-Test & 30 & 89,47 & 87 & 93 & 1,697 & $88,83-90,10$ \\
\hline
\end{tabular}

Berdasarkan tabel 3, diketahui bahwa rata-rata nilai saturasi oksigen pasien PPOK sebelum diberikan posisi Semi Fowler dari 30 responden adalah 89,47 (95\% CI: 88,83$90,10)$ dengan standar deviasi 1,697. Nilai saturasi oksigen terendah adalah sebesar 87 dan tertinggi yaitu 93 .

Tabel. 4

Saturasi Oksigen Responden

Setelah Diberikan Posisi Semi Fowler

\begin{tabular}{ccccccc}
\hline & $\mathrm{N}$ & Mean & Min & Max & SD & $95 \%$ CI \\
\hline Post-Test & 30 & 95,83 & 92 & 100 & 2,214 & $95,01-96,66$ \\
\hline
\end{tabular}

Berdasarkan tabel 4, data menunjukkan bahwa rata-rata nilai saturasi oksigen setelah diberikan posisi Semi Fowler dari 30 responden adalah 95,83 (95\% CI: 95,0196,66) dengan standar deviasi 2,214. Nilai saturasi oksigen terendah adalah 92 dan tertinggi yaitu 100 . 
Tabel. 5

Hasil Analisis Pre dan Post-Test

dengan Menggunakan Program Komputer

\begin{tabular}{cccc}
\hline & & Mean & p-Value \\
\hline \multirow{2}{*}{ Pair 1 } & Pre-Test & 89,47 & 0,000 \\
\cline { 2 - 4 } & Post-Test & 95,83 & 0,000 \\
\hline
\end{tabular}

Berdasarkan tabel 5, data menunjukkan bahwa ada pengaruh yang signifikan pada pelaksanaan intervensi Posisi Semi Fowler terhadap saturasi oksigen pasien PPOK. Hasil perhitungan dengan program komputer menunjukkan p-value 0,000 ( $\mathrm{p}<0,005)$, maka dapat disimpulkan bahwa terdapat pengaruh Posisi Semi Fowler terhadap saturasi oksigen pasien PPOK Rumah Sakit Santi Graha.

\section{PEMBAHASAN}

\section{Karakteristik Responden}

Responden pada penelitian ini yaitu sebanyak 30 orang penderita PPOK dengan usia 40-55 tahun yang mengalami hipoksemia. Dengan karakteristik umur responden, yang paling banyak menderita PPOK yaitu rentang umur 46-50 tahun. Hal ini sesuai dengan penelitian yang dilakukan pada 30 orang pasien PPOK di Rumah Sakit Paru dr. Ario Wirawan Salatiga yang dibagi menjadi 2 kelompok yaitu 15 orang pada kelompok posisi Tripod dan 15 orang pada Diaphragmatic Breathing Exercise. Penderita PPOK berada pada usia 56-65 tahun. Penelitian tersebut membuktikan bahwa semakin tinggi usia seseorang semakin besar juga resiko untuk terkena penyakit PPOK (Nurmalasari et al., 2017).

Jumlah penderita PPOK pada penelitian ini dominan pada laki-laki yaitu sebanyak 23 orang $(76,7 \%)$. Hasil ini membuktikan bahwa PPOK banyak menyerang laki-laki dibandingkan perempuan. Hal ini di karenakan laki-laki memiliki kebiasaan merokok. Konsumsi rokok yang berlebihan dapat merangsang produksi mukus pada sistem pernafasan yang kental yang dapat menurunkan pergerakan udara, sehingga menimbulkan pertumbuhan mikroorganisme. Penelitian yang dilakukan oleh Astriani et al., (2020) pada 30 orang responden PPOK di RSUD Kabupaten Buleleng menunjukkan $73,3 \%$ pasien PPOK diderita oleh laki-laki. Pada umumnya PPOK dapat terjadi pada laki-laki dan perempuan, tetapi laki-laki lebih beresiko dan insidennya lebih banyak.

\section{Nilai Saturasi Oksigen sebelum Pemberian Posisi Semi Fowler}

Nilai saturasi oksigen pada pasien PPOK dari 30 orang responden sebelum diberikan posisi Semi Fowler menunjukkan nilai rata-rata saturasi oksigen yaitu 89,47. Data ini menunjukkan nilai saturasi oksigen pada pasien PPOK sebelum diberikan posisi Semi Fowler sebagian besar mengalami hipoksemia sedang. Hal ini dikarenakan selain pemberian nebulizer untuk mengencerkan secret, sangat penting juga untuk memberikan therapy batuk efektif dan pemberian posisi yang nyaman seperti posisi Semi Fowler yang dapat memudahkan pasien dalam mengeluarkan secret. Sebelum diberikan posisi Semi Fowler sebagian besar pasien PPOK mengalami hipoksemia sedang. Hal ini berkaitan dengan faktor-faktor yang mempengaruhi hipoksemia pada penderita PPOK antara lain faktor genetik, faktor lingkungan dan faktor-faktor yang tidak diketahui. 
Faktor Lingkungan seperti kebiasaan merokok, polusi udara dan pemajanan di tempat kerja. Faktor-faktor lain yang tidak diketahui seperti jenis kelamin dan status sosial ekonomi. Penderita PPOK pada umumnya mengalami batuk-batuk, sesak nafas secara kronis dan menahun. Gejala tersebut diakibatkan oleh tumpukan mukus yang kental dan mengendap menyebabkan obstruksi jalan nafas yang mengakibatkan asupan oksigen tidak adekat sehingga terjadi penurunan saturasi oksigen. Penyembuhan PPOK secara medis tidak bisa secara tuntas, sehingga untuk mengencerkan mukus dilakukan dengan memberikan inhalasi atau nebulizer.

Selain itu, penderita PPOK juga diberikan therapy batuk efektif dan pemberian posisi yang nyaman untuk memudahkan mengeluarkan secret sehingga jalan nafas menjadi lancar dan peningkatan saturasi oksigen. Penelitian pada 29 responden pasien PPOK dari bulan April-Juni 2019 di RS Islam Jakarta Cempaka Putih untuk melihat nilai saturasi oksigen dengan pemberian pemberian fisioterapi dada, batuk efektif dan nebulizer. Rata-rata saturasi oksigen sebelum diberikan intervensi 93 dan setelah diberikan intervensi nilai saturasi oksigen sebesar 97. Hal ini membuktikan bahwa pemberian fisioterapi dada, batuk efektif dan nebulizer sangat efektif diberikan pada klien dengan pasien PPOK (Nurmayanti et al., 2019).

\section{Nilai Saturasi Oksigen sesudah Pemberian Posisi Semi Fowler}

Nilai saturasi oksigen pada pasien PPOK dari 30 orang responden setelah diberikan posisi Semi Fowler selama 30 menit menunjukkan nilai rata-rata 95,83. Data ini menunjukkan nilai saturasi oksigen pada pasien PPOK setelah diberikan posisi Semi Fowler sebagian besar mengalami peningkatan saturasi oksigen menjadi SaO2 normal. Hal ini menunjukkan bahwa pemberian posisi Semi Fowler mampu meningkatkan saturasi oksigen dengan memudahkan mengeluarkan secret dan melancarkan jalan nafas.

Tindakan untuk mengatasi penurunan saturasi oksigen adalah pemberian terapi baik terapi farmakologi maupun terapi non farmakologi. Terapi farmakologi seperti bronkodilator, steroid dan obat-obat tambahan lainya. Sedangkan terapi non farmakologi yaitu terapi oksigen jangka pajang dan rehabilitasi seperti latihan pernafasan serta pemberian posisi nyaman. Salah satu posisi nyaman yang diberikan pada pasien PPOK adalah posisi Semi Fowler. Pengaturan posisi Semi Fowler $45^{0}$ sangat efektif pada penyakit kardiopulmonari. Metode tersebut dapat mengurangi sekresi pulmonar dan mengurangi resiko penurunan dinding dada. Penelitian yang dilakukan oleh (Khasanah, 2019) pada 38 pasien CHF mengetahui perbedaan respirasi rate (RR) dan saturasi oksigen (SaO2) pada posisi Head Up, Semi Fowler dan Fowler. Rerata saturasi oksigen ( $\mathrm{SaO} 2)$, dari posisi Head Up ke Semi Fowler mengalami peningkatan 0.5 point dan dari posisi Semi Fowler ke Fowler juga mengalami peningkatan sebesar 0,2 point.

Beberapa penelitian yang dilakukan dapat meningkatkan nilai rata-rata saturasi oksigen. Seperti penelitian yang dilakukan oleh Qorisetyartha et al., (2018) pada 38 responden pasien TB Paru RSP dr Ario wirawan Salatiga. Nilai rata-rata saturasi oksigen sebelum diberikan intervensi adalah 94\% dan setelah diberikan intervensi menjadi 97\%. Hal ini menunjukkan bahwa Posisi Semi Fowler dengan Pursed Lip Breathing efektif untuk meningkatkan saturasi oksigen pasien TB paru. Demikian juga penelitian yang dilakukan oleh Astriani et al., (2020) pada 15 responden warga Bungkulan menunjukkan bahwa rata-rata saturasi oksigen tertinggi adalah $99 \%$ dan terendah adalah 91\% dengan rata-rata saturasi oksigen sebesar 94,53\%. Hal tersebut 
menunjukkan bahwa pemberian relaksasi nafas dengan ballon blowing dapat meningkatkan saturasi oksigen pada pasien PPOK.

\section{Pemberian Posisi Semi Fowler terhadap Saturasi Oksigen}

Hasil uji analisa data dengan menggunakan uji paired dependent t-test menunjukkan bahwa nilai $\rho<\alpha \quad(0.0000<0.05)$. Dengan demikian, ada pengaruh pemberian posisi Semi Fowler terhadap saturasi oksigen pada pasien PPOK di RS Santi Graha.

Sejalan dengan teori Kozier yang menyatakan bahwa ketika pasien yang mengalami kesulitan dalam bernapas diberikan posisi Semi Fowler, maka gravitasi akan menarik diafragma ke bawah, sehingga memungkinkan ekspansi dada dan ventilasi paru yang lebih besar. Ventilasi maksimal dapat membuka area atelektasis dan pengeluaran secret melalui jalan nafas. Saat dada mengembang dan tekanan dari abdomen pada diafragma menurun, maka oksigen di dalam paru-paru juga meningkat. Peningkatan oksigen di dalam paru-paru membantu memperingan kesukaran nafas dan sekaligus juga membantu meningkatkan saturasi oksigen serta mengurangi kerusakan membran alveolus akibat tertimbunnya cairan, sehingga perbaikan kondisi klien lebih cepat. Pemberian posisi tidur Semi Fowler dapat meningkatkan nilai saturasi oksigen pada penderita Congestive Heart Failure (Wijayati et al., 2019).

Penelitian yang dilakukan oleh Firdaus et al., (2019) pada 20 responden pasien asma bronkial menunjukkan adanya peningkatan nilai saturasi oksigen meningkat dari 92,60\% menjadi $98 \%$ setelah diberikan terapi oksigen dengan posisi Fowler. Studi kasus Mustikarani \& Mustofa (2020) pada 2 orang pasien dengan Stroke Hemoragik juga menunjukkan adanya peningkatan nilai saturasi oksigen, kasus I meningkat dari 95-98\% dan kasus II meningkat dari 94-98\%. Responden mengalami kenaikan saturasi oksigen setelah diberikan tindakan head of bed 300. Kebutuhan yang diperlukan pasien salah satunya adalah oksigenasi untuk meningkatkan suplai oksigen ke otak melalui pengaturan posisi dan pemberian oksigen. Posisi Semi Fowler juga dapat menurunkan sesak nafas yang dialami oleh pasien PPOK. Posisi Semi Fowler, dimana kepala dan tubuh dinaikkan $45^{\circ}$ membuat oksigen di dalam paru-paru semakin meningkat sehingga memperingan kesukaran napas (Suhatridjas \& Isnayati, 2020).

Penelitian Amiar \& Setiyono (2020) pada 12 responden pasien TB Paru menunjukkan adanya perubahan nilai saturasi oksigen setelah diberikan Semi Fowler yaitu dari 92,83\% menjadi 95,17\%. Derajat kemiringan Semi Fowler $30^{\circ}-45^{\circ}$ ini dapat membantu pengembangan paru dan mengurangi tekanan abdomen dari diafragma hanya dengan gaya gravitasi. Penelitian oleh Yulia et al., (2019) pada 30 responden pasien asma yang dibagi menjadi 2 kelompok yaitu kelompok 1 tidak diberikan intervensi dan kelompok 2 diberikan intervensi nafas dalam dan posisi Semi Fowler. Nilai saturasi oksigen sebelum diberikan intervensi yaitu 93,1\% menjadi 98,3\% setelah intervensi. Modifikasi posisi Semi Fowler dan teknik relaksasi nafas dapat meningkatkan oksigen dalam darah serta ventilasi paru dalam pemberian asuhan keperawatan.

\section{SIMPULAN}

Posisi Semi Fowler efektif dalam meningkkatkan saturasi oksigen pada pasien PPOK. Metode tersebut dapat mengurangi sekresi pulmonar dan mengurangi resiko penurunan dinding dada. Posisi Semi Fowler bisa meningkatkan expansi paru dan menurunkan frekuensi sesak napas dikarenakan dapat membantu otot pernapasan mengembang maksimal. 


\section{SARAN}

Diharapkan masyarakat yang mengalami kesukaran napas akibat PPOK untuk mampu mengatur posisi Semi Fowler saat istirahat agar mampu meringankan kesukaran napas secara mandiri dan non-farmakologis. Bagi pelayanan memberikan informasi dalam pengaplikasian pemberian posisi Semi Fowler sebagai salah satu alternatif untuk mengurangi kesukaran bernapas akibat PPOK kepada seluruh profesi keperawatan.

Peneliti selanjutnya diharapkan untuk lebih memperbanyak jumlah sampel dan mengembangkan variabel yang berbeda untuk mendapatkan hasil yang lebih variatif dan memberikan dampak yang positif bagi pengembangan konsep dan ilmu keperawatan dalam hubungannya dengan pemberian posisi Semi Fowler. Peneliti juga berharap bahwa penelitian ini dapat digunakan sebagai bahan kajian dasar dalam melaksanakan penelitian lebih lanjut yang berkaitan dengan topik permasalahan yang sama yaitu berkaitan dengan saturasi oksigen dan pemberian posisi Semi Fowler.

\section{DAFTAR PUSTAKA}

Amiar, W., \& Setiyono, E. (2020). Efektivitas Pemberian Teknik Pernafasan Pursed Lips Breathing dan Posisi Semi Fowler terhadap Peningkatan Saturasi Oksigen pada Pasien TB Paru. Indonesian Journal of Nursing Science and Practice, 3(1), 7-13. https://doi.org/10.24853/ijnsp.v3i1.7-13

Astriani, N. M. D. Y., Ariana, P. A., Dewi, P. I. S., Heri, M., Cita, E. E. (2020). PKM : Pelatihan Relaksasi Nafas Ballon Blowing untuk Meningkatkan Saturasi Oksigen pada Warga Desa Bungkulan Singaraja. VIVABIO: Jurnal Pengabdian Multidisiplin, 2, 1-7. https://doi.org/10.35799/vivabio.2.2.2020.30279

Astriani, N. M. D. Y., Aryawan, K. Y., \& Heri, M. (2020). Teknik Clapping dan Vibrasi Meningkatkan Saturasi Oksigen Pasien PPOK. Jurnal Keperawatan Silampari, 4(1), 248-256. https://doi.org/10.31539/jks.v4i1.1767

Astriani, N. M. D. Y., Dewi, P. I. S., \& Yanti, K. H. (2020). Relaksasi Pernafasan dengan Teknik Ballon Blowing terhadap Peningkatan Saturasi Oksigen pada Pasien PPOK. Jurnal Keperawatan Silampari, 3(2), 426-435. https://doi.org/10.31539/jks.v3i2.1049

Dinas Kesehatan. (2019). Profil Kesehatan Kabupaten Buleleng Tahun 2018. https://www.diskes.baliprov.go.id/download/profil-kesehatan-buleleng-tahun2018/

Firdaus, S., Ehwan, M. M., \& Rachmadi, A. (2019). Efektivitas Pemberian Oksigen Posisi Semi Fowler dan Fowler terhadap Perubahan Saturasi pada Pasien Asma Bronkial Persisten Ringan. JKEP, 4(1), 31-43. https://doi.org/10.32668/jkep.v4i1.278

J, H., Padila, P., Andri, J., Andrianto, M., \& Yanti, L. (2020). Frekuensi Pernafasan Anak Penderita Asma Menggunakan Intervensi Tiup Super Bubbles dan Meniup Baling Baling Bambu. Journal of Telenursing (JOTING), 2(2), 119-126. https://doi.org/10.31539/joting.v2i2.1409

Kementerian Kesehatan RI. (2018). Hasil Utama Riset Kesehatan Dasar 2018. https://kesmas.kemkes.go.id/assets/upload/dir_519d41d8cd98f00/files/Hasilriskesdas-2018_1274.pdf

Khasanah, S. (2019). Perbedaan Saturasi Oksigen dan Respirasi Rate Pasien Congestive Heart Failure pada Perubahan Posisi. Jurnal Ilmu Keperawatan Medikal Bedah, 2(1), 1-54. https://doi.org/10.32584/jikmb.v2i1.157

Mustikarani, A., \& Mustofa, A. (2020). Peningkatan Saturasi Oksigen pada Pasien 
Stroke Melalui Pemberian Posisi Head Up. Ners Muda, 1(2), 114-119. https://doi.org/10.26714/nm.v1i2.5750

Nurmalasari, S., Kristiyawati, P., \& SN, M. S. A. (2017). Efektifitas Diaphragmatic Breathing Exercise terhadap Peningkatan Saturasi Oksigen pada Pasien PPOK di RS Paru Dr Ario Wirawan Salatiga. Jurnal Ilmu Keperawatan dan Kebidanan, 6, 1-12. e-journal/index.php/ilmukeperawatan/article/view/652

Nurmayanti, N., Waluyo, A., Jumaiyah, W., \& Azzam, R. (2019). Pengaruh Fisioterapi Dada, Batuk Efektif dan Nebulizer terhadap Peningkatan Saturasi Oksigen dalam Darah pada Pasien PPOK. Jurnal Keperawatan Silampari, 3(1), 362-371. https://doi.org/10.31539/jks.v3i1.836

Padila, P., Febriawati, H., Andri, J., \& Dori, R. (2019). Perawatan Infeksi Saluran Pernafasan Akut (ISPA) pada Balita. Jurnal Kesmas Asclepius, 1(1), 25-34. https://doi.org/10.31539/jka.v1i1.526

Padila, P., J, H., Yanti, L., Setiawati, S., \& Andri, J. (2020). Meniup Super Bubbles dan Baling-Baling Bamboo pada Anak Penderita Pneumonia. Jurnal Keperawatan Silampari, 4(1), 112-119. https://doi.org/10.31539/jks.v4i1.1545

Pratama, M., Gurning, F., \& Suharto, S. (2019). Implementasi Penanggulangan Tuberkulosis di Puskesmas Glugur Darat Kota Medan. Jurnal Kesmas Asclepius, 1(2), 196-205. https://doi.org/10.31539/jka.v1i2.961

Qorisetyartha, N., Kristiyawati, S. P., \& Arief, M. S. (2018). Efektivitas Pursed Lips Breathing dengan Diaphragma Breathing terhadap $\mathrm{SaO}_{2}$ Pasien Pneumonia di RSP Dr. Ariowirawan Salatiga. Jurnal ILmu Keperawatan dan Kebidanan, 6, 115.

http://ejournal.stikestelogorejo.ac.id/index.php/ilmukeperawatan/article/view/636/ 634

Sahrudi, S., \& Satria, M. (2020). Posisi Semi Fowler Menurunkan Frekuensi Napas. Jurnal Antara Keperawatan, 3(2), 59-65. https://doi.org/10.37063/antaraperawat.v3i2.181

Suhatridjas, S., \& Isnayati, I. (2020). Posisi Semi Fowler terhadap Respiratory Rate untuk Menurunkan Sesak pada Pasien TB Paru. Jurnal Keperawatan Silampari, 3(2), 566-575. https://doi.org/10.31539/jks.v3i2.1116

Ummah, A. K., \& Alivian, G. N. (2020). Implementation of Pursed Lip Breathing and Semi Fowler Position in COPD Patients which Get Nebulizer in IGD: A Literature Review. Jurnal of Bionursing, 2(3), 208-214. https://doi.org/10.20884/bion.v2i3.74

Wijayati, S., Ningrum, D. H., \& Putrono, P. (2019). Pengaruh Posisi Tidur Semi Fowler $45^{\circ}$ terhadap Kenaikan Nilai Saturasi Oksigen pada Pasien Gagal Jantung Kongestif di RSUD Loekmono Hadi Kudus. Medica Hospitalia: Journal of Clinical Medicine, 6(1), 13-19. https://doi.org/10.36408/mhjcm.v6i1.372

Yulia, A., Dahrizal, D., \& Lestari, W. (2019). Pengaruh Nafas Dalam dan Posisi terhadap Saturasi Oksigen dan Frekuensi Nafas pada Pasien Asma. Jurnal Keperawatan Raflesia, 1(1), 67-75. https://doi.org/10.33088/jkr.v1i1.398 